\title{
ALC の空隙構造と凍結挙動
}

\author{
多田 眞作*
}

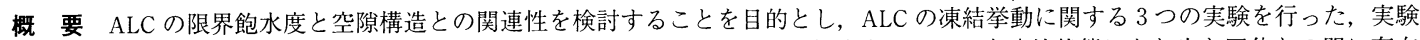
1 として示差走査熱量計による相変化熱の測定により，吸着水が固体表面の拘束力によって未凍結状態になり水と固体との間に存在 することを示し, 実験 2 として凍結過程における長さ変化の測定により限界飽水度を実際に測定し, その飽水度に対応する水分が空 隙中のどの部分に存在するのかを示した。実験 3 として実際に限界飽水度の水分量に調製した供試体を凍結させ, 低温走査電子顕微 鏡で直接観察し, 気泡中の水の状態を確認した。これらの結果から, ALCの限界飽水度はマトリックス部分に存在する細孔が飽水状 態となり, さらに気泡部分の約 $6 \%$ にも水分が存在する状態であると結論し, 限界飽水度をALCのかさ密度の関数として表した。 キーワード：ALC, 空隙構造, 凍結挙動, 限界飽水度, 吸着水, 寸法変化, 試験法
\end{abstract}

\section{1.はじめに}

コンクリートの耐凍性を評価するための RILEM 試験 法“限界飽水度法” (Degree of Critical Saturation Method, 1977） ${ }^{1)}$ は ASTM 法に比較して新しい試験方法 であるが, 我国でもその有効性が検証され2), ALCへの 適用事例もいくつか報告されている324)5)。

限界飽水度法では, 凍結による内部的損傷が初めて検 出できる最小の飽水度として定義される限界飽水度（以 下 RILEMの表記にならない S $r$ と略記する）を実験的 に求め, 使用中に生じる可能性のある含水率レベルとこ の S c r との差によって耐凍結融解抵抗性が判定される。 限界飽水度（Scr） は飽水度（空隙基準の含水率）を種 々変化させた試料を凍結条件下におき, この時の長さ変 化もしくは動弾性率の变化の測定から求めることとされ ている。そして ALC の場合でも, 飽水度がScr 以上の ものは凍結時に長さ変化が収縮から膨張に転じたり, 動 弾性率が低下し始めるなど, 飽水度が S r r 以下のものに 対し明白な差が認められるので S cr の判定そのものは比 較的容易である ${ }^{6) 7) 8) 。 ~}$

しかし，ある飽水度を境界として，なぜこのような大 きな差が生じるのかについては十分な説明が与えられて いない。したがって, ALCの耐凍結融解性の向上を意 図して空隙構造を如何に設計すべきかという課題に対し て，利用できる情報を与えるには至っていないと思われ る。特に，Scrと ALCのかさ密度との関連性が明確で ないため, ALCのかさ密度を変えた場合にその都度実 験を行なわないと結果が予測できないという問題もあ

* (株)ラスト (正会員)
る。

そこで本研究では, ALCの限界飽水度 $(\mathrm{Scr})$ と空陌 構造との関連性を検討することを最終目的とし, ALC の凍結挙動に関する 3 つの実験を行った。実験 1 では吸 着水は固体表面からの拘束力によって, 水結している自 由水と固体との間に未凍結状態で存在することを示すこ とを目的とした。実験 2 ではS $c r$ を実際に測定し，その 飽水度に対応する水分が, 空隙中のどの部分に存在する のかを示すことを目的とした。実験 3 では実際にS cr の 水分量の状態で凍結させた供試体を低温走査電顕で直接 観察し, 空隙構造中の水の配置についての具体的なイメ ージを得，実験 $1 ， 2$ の結果との整合性を検証すること を目的とした。

これらの実験結果を取りまとめ, 考察を加えた結果, ALC の限界飽水度 $(S c r)$ と空隙構造との関係の一つと して, S $r$ を ALCのかさ密度の関数として表すことが できたので以下に報告する。

\section{2. 試料及び実験方法}

\section{1 試 料}

現在, 国内で量産されているALC はかさ密度 0.50 0.55 程度のものが多く, 本実験では 0.503 のものを用 いた。また比較用として空隙構造が大きく異なる，かさ 密度が $0.355,0.641$ のものも試作し実験に供した。こ れらの試料の原材料, 養生条件等を表-1に示す。これ らの試料はいずれも実験室において，プレフォーム法を 用い， $4 \times 4 \times 16 \mathrm{~cm}$ の型枠で製作されたものである。こ のため, ガス発泡法で製造される通常の ALCに対し， マトリックス部分の細孔構造に大差はないが, 気泡構造 には若干の違いがある。 
表-1 試 料

\begin{tabular}{|c|c|c|c|c|}
\hline & かさ密度 $\left(\mathrm{g} / \mathrm{C} \mathbf{n}^{3}\right)$ & 全空腺率 & 主原材料 & 養生方法 \\
\hline $\begin{array}{l}\text { オートクレープ養生した } \\
\text { 気泡コンクリート (ALC) }\end{array}$ & $\begin{array}{l}0.355 \\
0.503 \\
0.641\end{array}$ & $\begin{array}{l}0.865 \\
0.808 \\
0.758\end{array}$ & $\begin{array}{l}\text { 石英粉、ポルトラ } \\
\text { ンドセメント } \\
\text { 急硬性セメント、 } \\
\text { 界面活性剂 }\end{array}$ & $\begin{array}{l}\text { オートクレーブ養生 } \\
180^{\circ} \mathrm{C} ， 10 \text { 気压，8時間 }\end{array}$ \\
\hline
\end{tabular}

表-2 実験方法一覧

\begin{tabular}{|c|c|c|c|}
\hline 実験名 & 装置 & 供試体寸法・試験方法 & 試験前の調整条件 \\
\hline $\begin{array}{l}\text { 実畭! } \\
\text { 末東結水の測定 }\end{array}$ & $\begin{array}{l}\text { 示差走査熱量計(DSC) } \\
\text { セイコー電子工業 } \\
\text { SSC-560u }\end{array}$ & $\begin{array}{l}100 \mu \ell \\
20^{\circ} \mathrm{C} \text { から }-50^{\circ} \mathrm{C} ま て ゙ \\
2{ }^{\circ} \mathrm{C} / \mathbb{m} \text { inで冷却し } \\
\text { 相変化熱を測定 }\end{array}$ & 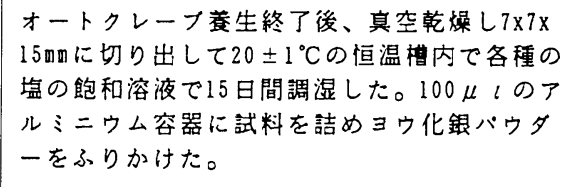 \\
\hline $\begin{array}{l}\text { 実験2 } \\
\text { 凍結中の長さ } \\
\text { 変化の測定 }\end{array}$ & $\begin{array}{l}\text { 差動トランス、アンフ } \\
\text { Macintosh SE、 } \\
\text { A/Dコンバータ } \\
\text { 低温メタノール循琼指 }\end{array}$ & $\begin{array}{l}4 \times 4 \times 16 \mathrm{~cm}, \text { RILEMに淮拋 } \\
5^{\circ} \mathrm{C} \text { から }-20^{\circ} \mathrm{C} \text { ま } 3^{\circ} \mathrm{C} / \mathrm{hr} \\
\text { で令却し試料中心温度と } \\
\text { 長さ変化率を測定 }\end{array}$ & 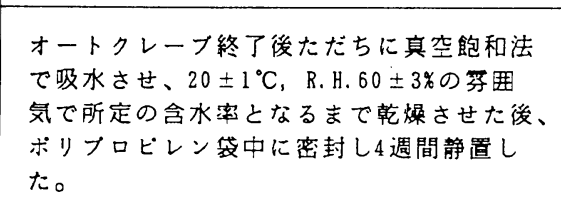 \\
\hline $\begin{array}{l}\text { 実䀫3 } \\
\text { 逨結中の気泡 } \\
\text { 表面の観察 }\end{array}$ & $\begin{array}{l}\text { 日立S-800電界放射型 } \\
\text { 走查電子顕微鏡 (FE-SEM) } \\
\text { クライオステージ }\end{array}$ & $\begin{array}{l}5 \phi \times 10 \text { 回 } \\
\text { 鏡体内で-190 } \mathrm{C} \text { C冷 } \\
\text { 却した後割断し、気 } \\
\text { 泡断面の水を観察 }\end{array}$ & 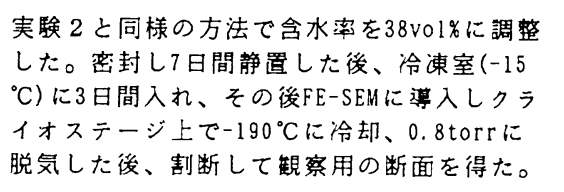 \\
\hline
\end{tabular}

表-3 ALC の空隙構造及び水分量に関する記号の説明

\begin{tabular}{|c|c|c|c|c|c|c|c|}
\hline 名 称 & 記号 & 定 & 単 位 & 称 & 記号 & 定 & 単 位 \\
\hline A L Cの重量 & $Q$ & $105^{\circ} \mathrm{C}$ 恒量時の質量 & g & $\begin{array}{l}\text { マトリックス } \\
\text { のかさ密度 }\end{array}$ & $d m$ & $Q /(V-V p a)$ & $\mathrm{g} / \mathrm{cm}^{3}$ \\
\hline A L Cの体積 & $V$ & $\begin{array}{l}\text { アルキメデス法で測定され } \\
\text { た体積 }\end{array}$ & $\mathrm{cm}^{3}$ & 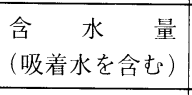 & $V w$ & $105^{\circ} \mathrm{C}$ で脱着する全水分量 & $\mathrm{cm}^{3}$ \\
\hline かさ密度 & $d$ & $Q / V$ & $\mathrm{~g} / \mathrm{cm}^{3}$ & 体積含 水率 & $W$ & $(V w / V) \times 100$ & $\%$ \\
\hline 細 孔 量 & $V p m$ & マトリックス部の空隙量 & $\mathrm{cm}^{3}$ & 飽 水 度 & $S$ & $(V w / V p) \times 100$ & $\%$ \\
\hline 気 泡 量 & $V p a$ & $\begin{array}{l}\text { 発泡剂により導入された気 } \\
\text { 泡量 }\end{array}$ & $\mathrm{cm}^{3}$ & 限界飽 水度 & $S c r$ & $\begin{array}{l}\text { 凍結による内部損傷が検出 } \\
\text { できる最小の飽水度 }\end{array}$ & $\%$ \\
\hline 全空 隙量 & $V p$ & $V p m+V p a$ & $\mathrm{~cm}^{3}$ & B E T 比表面積 & $A$ & $\begin{array}{l}\text { BET 法で測定された空隙 } \\
\text { の内部表面積 }\end{array}$ & $\mathrm{cm}^{2} / \mathrm{g}$ \\
\hline 全空 隙率 & $P$ & $V p / V$ & - & 統計的吸着膜厚 & $t$ & $V w / A$ & $10^{-8} \mathrm{~cm}$ \\
\hline 真 密 度 & $d s$ & $Q /(V-V p)$ & $\mathrm{g} / \mathrm{cm}^{3}$ & & & & \\
\hline
\end{tabular}

\section{2 実験方法}

各実験に使用した装置, 実験方法, 供試体寸法, 供試 体の試験前の調製条件等をまとめて表-2に示す。また RILEM “限界飽水度法”には，用語の中に飽水度を始 めとして一般的でないものがいくつかある。そこで，こ れらをALCの空隙構造のパラメータとして本論文で使 用している特殊な用語と共に，その定義を明確にするた
め一覧表にまとめ，表-3に示した。またALC の空隙構 造のパラメー夕相互の関係については図-1に示してあ る。

(1) 未凍結水の測定

供試体を $4 \times 4 \times 16 \mathrm{~cm}$ の型枠を用いて製作し，オート クレーブ養生後ただちに真空デシケー夕に導入して炭酸 化を防止しながら乾燥した。これらを $7 \times 7 \times 15 \mathrm{~mm}$ の 


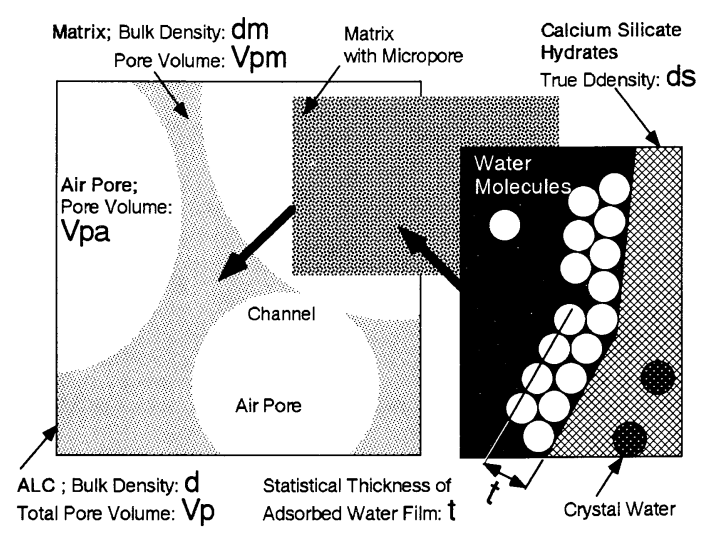

图-1ＡLC の空隙構造と水分の配置の模式図

寸法に切り出レ, $20 \pm 1{ }^{\circ} \mathrm{C}$ の恒温槽内におかれた各種 の塩の飽和溶液の入ったデシケー夕に入れ，それぞれ $66 ， 75 ， 85 ， 90 ， 93 ， 95 ， 98 \%$ の相対湿度条件下で 15 日間水分を調整した。高い含水率の試料は相対湿度によ る水分の調整が難しいので, 真空飽和法で飽水状態にし た後, $20{ }^{\circ} \mathrm{C}$, R. H. $60 \%$ の環境で徐々に乾燥させ, 所 定の水分量とした後ポリエチレン袋中で密封し 15 日間 静置した。

次にこれらの試料を示差走查熱量計（DSC）の測定に 供した。アルミニウムの容器 $(100 \mu l)$ に容器との密着 性の確保に注意して試料をセットし, 核生成助剂として ヨウ化銀パウダーを試料の表面にふりかけた。

DSC はセイコー電子工業社製の SSC-560 u を使用 し, $20{ }^{\circ} \mathrm{C}$ から $-50{ }^{\circ} \mathrm{C}$ まで $2{ }^{\circ} \mathrm{C} / \mathrm{min}$ の冷却速度で運転 した。またDSCの装置定数はベンゾフェノン（融点 $\left.47.9{ }^{\circ} \mathrm{C}\right)$, 純水 $\left(0.0{ }^{\circ} \mathrm{C}\right)$, 水銀 $\left(-38.3^{\circ} \mathrm{C}\right)$ によって 求めた。

(2) 凍結中の長さ変化の測定

供試体は DSC 測定の場合の高含水率試料と同様な手 段で水分量を調整したが，供試体の断面が比較的大きい ので密封後の静置時間は 4 週間とした。またそれぞれの かさ密度の ALC につき, 目標飽水度を $5,20,30$, $35 ， 40 ， 42 ， 45 ， 50 ， 52 ， 55 ， 60 ， 65 ， 70$ の 13 段階に 調整した。供試体をポリプロピレン製の袋中に密封した まま試験セルにセットし，メタノールを冷媒として冷却 速度 $3{ }^{\circ} \mathrm{C} / \mathrm{hr}$, 温度範囲 $+5{ }^{\circ} \mathrm{C} \sim-20{ }^{\circ} \mathrm{C}$ で凍結を行なっ た。この間の長さ変化は, 石英ガラスを介して差動卜ラ ンスで測定した。試料中心の温度は直径 $50 \mu \mathrm{m}$ の $\mathrm{K}$ 熱 電対を用いてすべての試料について測定した。これらの アナログ電圧信号はコンピュータ（Macintosh SE）に直 接取付けた 12 ビットの A/D コンバータで $200 \mathrm{~Hz}$ でサ ンプリングした。また冷却速度は様々な飽水度の試料の
中でも最も乾燥した試料（飽水度 5\%) の温度変化を予 備実験で測定して決定した。これは乾燥したものほど熱 伝導率が小さいため, 槽内温度と試料中心温度を一致さ せることが最も困難であることによる。

\section{(3) 凍結中の気泡の観察}

かさ密度 0.503 で約 $5 \phi-7 \mathrm{~mm}$ の寸法に切り出した 試料を, 上記の高含水率試料の調整条件と同様の方法で 飽水度 47.5 及び $78 \%$ に調整した。密封したまま 7 日間 静置した後, $-15{ }^{\circ} \mathrm{C}$ の冷蔵庫に 3 日間入れ, 次いでク ライオ装置を有する電界放射型走査電子顕微鏡 （FE-SEM）の試料室に導入して液体窒素温度に冷却し た。その後, 0.8 torr に脱気し, 鏡体内で試料を割断し てフレッシュな観察面を得た。試料表面への金の蒸着は 行なわず, 加速電圧 $5 \mathrm{kv}$ で観察した。

このような観察では, 加速電圧を大きくとれないた め, 倍率的にも ALC の気泡面の観察に留まるが, 気泡 の表面にはある条件下で, 水と紛らわしい結晶が存在す ることがある。特に水中養生した硬化セメントペースト では水酸化カルシウムが, 屋外暴露したALCでは炭酸 カルシウムやエトリンガイトが気泡表面に大きく成長す ることがあり，これを氷と見䛊る可能性がある。このた め冷却時の観察後に試料ステージの温度を上げて引き続 き観察し，氷が昇華することを確認した。

\section{3. 実験結果と考察}

\section{1 未凍結水の測定（実験 1）}

(1) 実験結果

かさ密度 $d$ が 0.503 の ALC 試料についての DSC の測 定結果を図-2に示す9)。各曲線はそれぞれ異なった相対 湿度で平衡含水率に到った各試料のものであり, その違 いは図中に相対湿度で示してある。比較のために水分量 のかなり大きい試料も測定したが,この場合については 飽水度 $(S)$ を用いて $S=25$ で示している。

DSC が検出した熱量は, 試料中の水分の相変化熱で あり，その凝固点は明らかに二つに分離し，2 種類の性 質の水分の存在を予想させる。一つはー $7.2{ }^{\circ} \mathrm{C}$ から一 $17.7{ }^{\circ} \mathrm{C}$ の間で凍結が生じていると見られる水分で, こ の凝固熱が示す発熱ピークを第一ピークと呼ぶことにす る。次に $-37{ }^{\circ} \mathrm{C}$ 付近で凍結すると見られる微量な水分 があり,この凝固熱が示す発熱ピークを第二ピークと呼 ぶことにする。これ以外の熱量はー $60{ }^{\circ} \mathrm{C}$ までの冷却に おいては, 最高の感度でも検出できなかった。またこの 第二ピークについても, 相対湿度 $66 \%$ 調湿品を含めて これ以下の相対湿度で調湿したものについては発熱を検 出できなかった。相対湿度 $66 \%$ の平衡含水率として定 まる水分は, $105{ }^{\circ} \mathrm{C}$ で蒸発するがー $60{ }^{\circ} \mathrm{C}$ までは凍結し ない水分であり, 実用上の不凍結水と考えて良いと思わ 


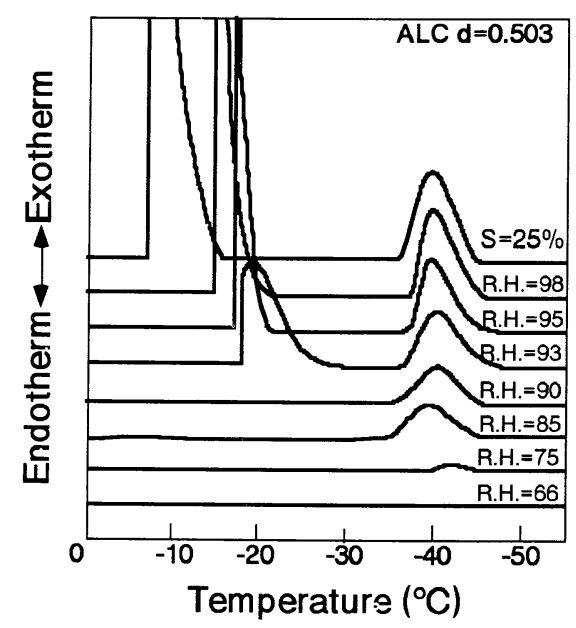

図-2ＡLC の飽水度と水分の相変化温度

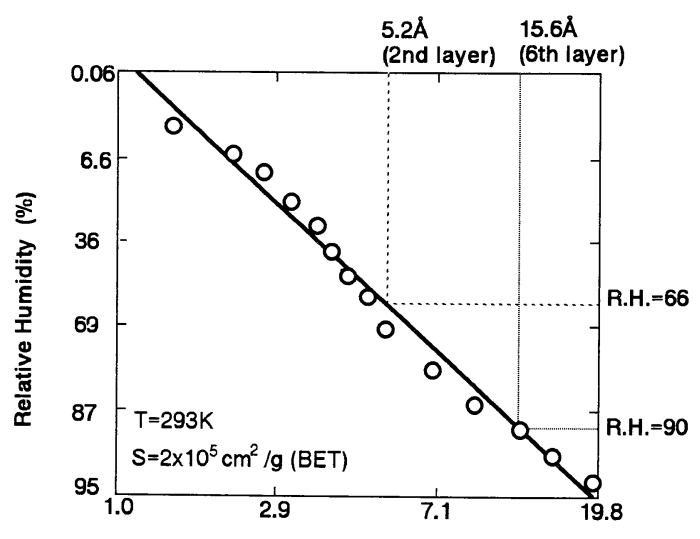

Statistical Thickness of Adsorbed Water Film: $t\left(10^{-8} \mathrm{~cm}\right)$

\section{図-3 ALC に吸着された水分の統計的吸着膜厚と相対湿度 の関係}

れる。この水分量はいわゆる気乾状態の水分量に近いも のであり，飽水度に換算すると $1.8 \%$ 程度に過ぎない。

(2) 考察

相対湿度によって定まる吸着水分量は，すでにALC

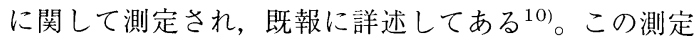
值を用いて, 相対湿度によって定まる吸着水分量 $V w$ が，固体表面からどの程度の距離に存在するのかを検討 するため, 統計的吸着膜厚 $t$ を次式で定める。

$$
t=V w / Q \cdot A
$$

ここで $A$ はBET 比表面積， $Q$ は試料の重量である。 吸着水膜の厚さは本来, 水分子の直径約 2.6 オングスト ロームの整数倍になるはずであるから， $t$ はあくまでも
統計的な意味で計算されるものである。相対湿度の対数 を 2 度とり，統計的吸着膜厚を対数にとると図-3に示 すような直線が得られる。

図中に記入してあるように，相対湿度 $66 \%$ の平衡含 水率として定まる水分は統計的な吸着水膜の厚さとして はほぼ 2 分子層に相当するので, ファン・デル・ワール ス力などの影響のもとで，極めて強く拘束された水であ ろうと考えられる。これに対し，第二ピークを形成する 水分は固体表面からの力を受け, 拘束されてはいるがー $37{ }^{\circ} \mathrm{C}$ 付近で凝固する水であり，相対湿度 $90 \%$ の平衡含 水率として定まる 6 分子層までの統計的吸着膜厚に相当 する。また第一ピークの発熱に関わる水分は，いわゆる 自由水と考えられるが，図-2に示されているように水 分量に応じた凝固点降下が見られる。

これらの 3 種類の水分は, ALC 以外の材料において も，セメントペースト 11)12)13) はもとよりレンガ14)15), 親水性合成ポリマー ${ }^{16)}$, ショ糖溶液 ${ }^{17)}$ な゙でも水分量 の変化に応じて明確に分離されて検出されている。特に 第二ピークの水分は固体表面の吸着サイト即ち親水基の 密度と関係が深いと言われ ${ }^{16)}$ ，表面改質を行なって適 当な疎水基で親水基を置換したものでは，第二ピークが 消失すると報告されている ${ }^{18)}$ 。Zettlemoyer は固体表面 の親水基と吸着水との水素結合の影響は 6 分子層まで及 ぶと述べていることから ${ }^{19)}$ ，第二ピークを形成する水 分もまた固体表面からの拘束力により凝固点降下を示し ているものと考えられる。このような水分は, RILEM の限界飽水度法に規定されるー $20{ }^{\circ} \mathrm{C}$ までの凍結温度の 範囲にあっては未凍結水として, 固体と水（凍結した自 由水）との間に存在することになる。そして固体表面に 対し垂直方向には強く拘束されているものの, 固体表面 に対して平行の方向には容易に移動できるといわれてい



\section{2 凍結中の長さ変化と限界飽水度の測定 (実験 2)}

\section{(1) 実験結果}

かさ密度 0.503 の ALCについての凍結条件下での長 さ変化と温度の関係を図-4 に示す。3 種類のかさ密度そ れぞれにつき飽水度を 13 水準, 合計 39 個の試料の測定 を行なったが, ここではかさ密度 0.503 の場合のみを図 -4 に示す。この図によると長さ変化の傾向として, 飽 水度に応じて熱収縮の外挿值から収縮するものと膨張す るものとに区分されるので，それぞれ典型的なもののみ を示してある。どのかさ密度の試験体についても, 飽水 度がある大きさになると収縮から膨張に転ずる傾向が見 られ，その飽水度はかさ密度 0.503 の ALC で 45\%程度 であることがわかる。この点をより明確に示すために， RILEM の定義に従い, 熱収縮の外挿值から $-17{ }^{\circ} \mathrm{C} に お ~$ 


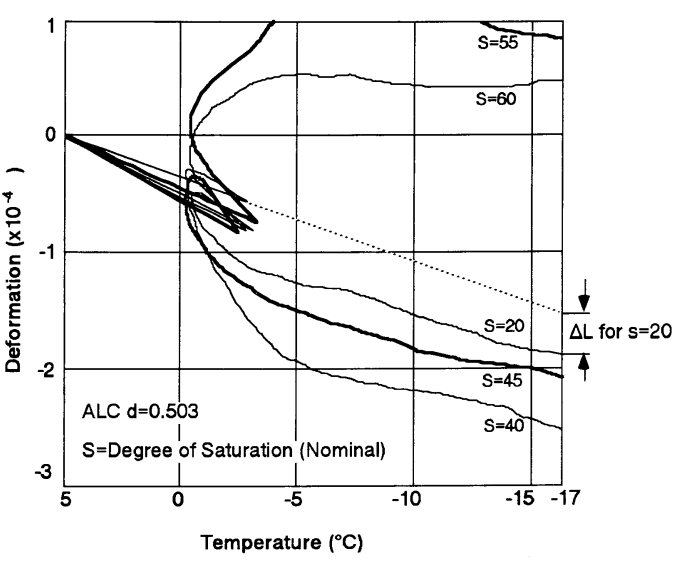

図-4 ALC の凍結中の長さ変化

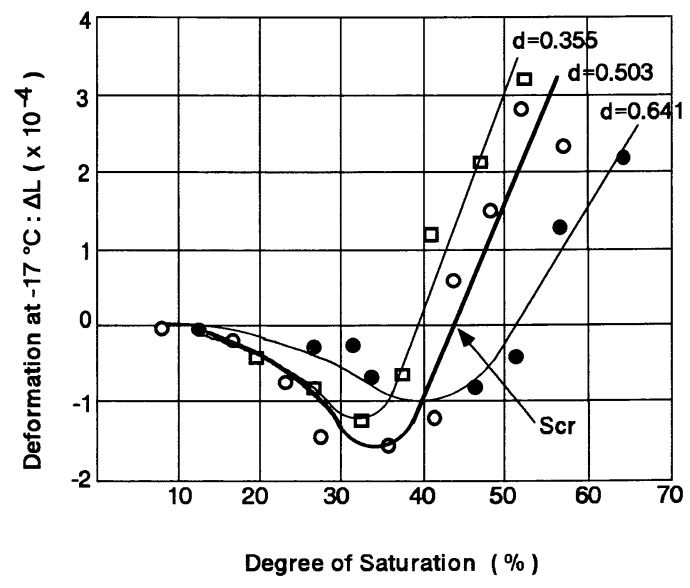

図-5 ALC の凍結中の長さ変化の飽水度への依存性

ける長さ変化の差を取って，これをその飽水度における 長さ変化量 $\Delta L$ とした。この長さ変化量と飽水度をプ ロットしたのが図-5である。図中に示される収縮側か ら膨張側に移行する点が, RILEM の定義する限界飽水 度 Scr である。この図から Scr は, かさ密度 0.355, 0.503，0.641のALCについてそれぞれ約 38，44，52\% と求められる。

\section{(2) 考察}

ALC の空隙の分布と，そこに存在することのできる

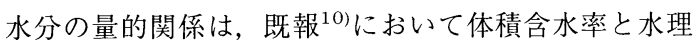
半径の関係として測定されている。この測定值を用い て, かさ密度 0.503 の試料について，体積含水率から換 算した飽水度と空隙半径の関係を図-6に示す。図-5に おいて限界飽水度 S $c r$ として測定された水分量 $44 \%$ に 対応する空隙領域は, 細孔の領域をすべて含み, さらに 気泡の領域も若干含む範囲のものであることがわかる。

限界飽水度以下の含水状態の大部分の試料は凍結過程

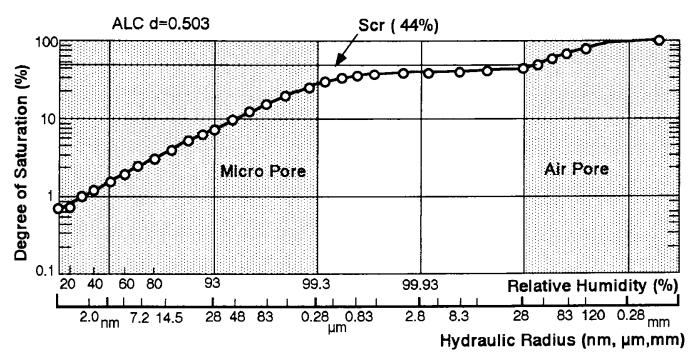

図-6 ALC の空隙半径と飽水度の関係

で熱収縮值よりもさらに収縮した。この含水状態では気 泡内に氷が成長できる余地が十分あり, 従って常圧を維 持したまま未凍結水が氷に変化しうる。この未凍結水は 固体と水との界面を移動し, 水と空気の界面に存在する 吸着水膜に至って凍結すると考えられる。この状態で未 凍結吸着水の膜厚は減じ, 乾燥収縮のような状態となっ て収縮が起こるのではないかと考えられる。しかし，こ の点についてはまだ想像の域を出ず，今後乾燥収縮など 別の分野の寸法変化に関する知見も取り入れて検討をす る必要があろう。

\section{3 凍結中の気泡の観察（実験 3）}

\section{(1) 実験結果}

この実験に用いた試料の飽水度は $47.5 \%$ 上記の実 験で求めたかさ密度 0.503 の試料の Scr $(44 \%)$ よりも やや飽水度が大きい。これは気泡と気泡の間に存在する マトリックス部分の空隙（細孔，全空隙量の $42 \%$ ）が 飽水した状態となっており, さらに一部の小気泡にも水 分が存在すると考えられる状態である。この含水状態で 凍結したものの気泡断面を写真-1，2，3に示す。また 気泡のかなりの部分が水で満たされていたと考えられる 飽水度 $78 \%$ の試料の凍結時の気泡断面を写真 $-4,5$ に 示す。

写真-1 の中央の大きな気泡（直径約 $0.5 \mathrm{~mm}$ ）の表面 には，わずかに氷が生成しているが，その右側のより小 さい 3 個の気泡ではほとんどの空間が水で占有されてい る。特に 3 個のうちの中央の最も小さい気泡は完全に氷 で満たされている。写真-2 はこの視野をさらに 2 倍に 拡大したものである。凍結前の気泡中にはこのような形 で水分が存在しないことを光学顕微鏡で確認しているの で，観察される水はマトリックス中の水分が移動して来 たものと考えざるを得ない。

\section{(2) 考 察}

飽水度 78\%の試料では, 写真-5 の右下に見られるよ うな, 凍結に関係すると見られる損傷が観察されるが, 限界飽水度に近い飽水度 $(47.5 \%)$ の試料（写真-1, 2，3）にはこのようなクラックは全く見られない。 RILEM の考える限界飽水度は，あくまで内部的な損傷 




写真-1 飽水度 47.5\%で凍結した ALC の気泡表面の水

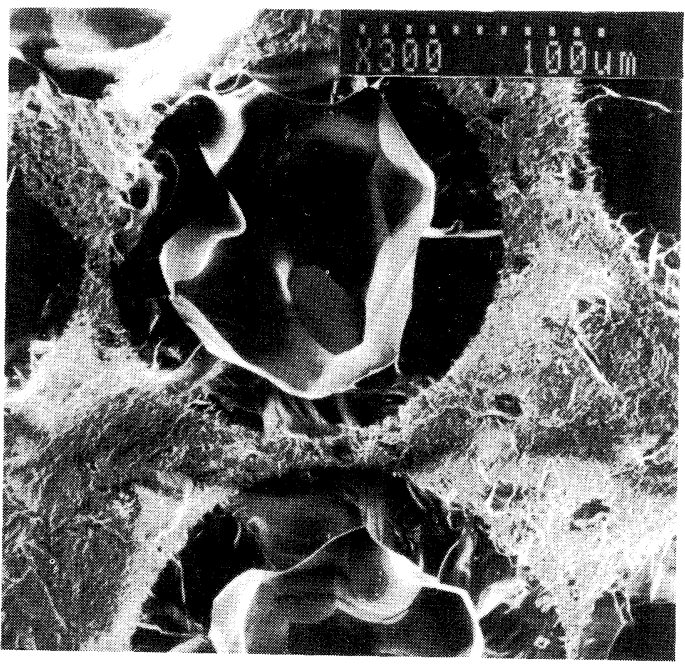

写真-3 飽水度 47.5\%で凍結した ALC の気泡表面の水

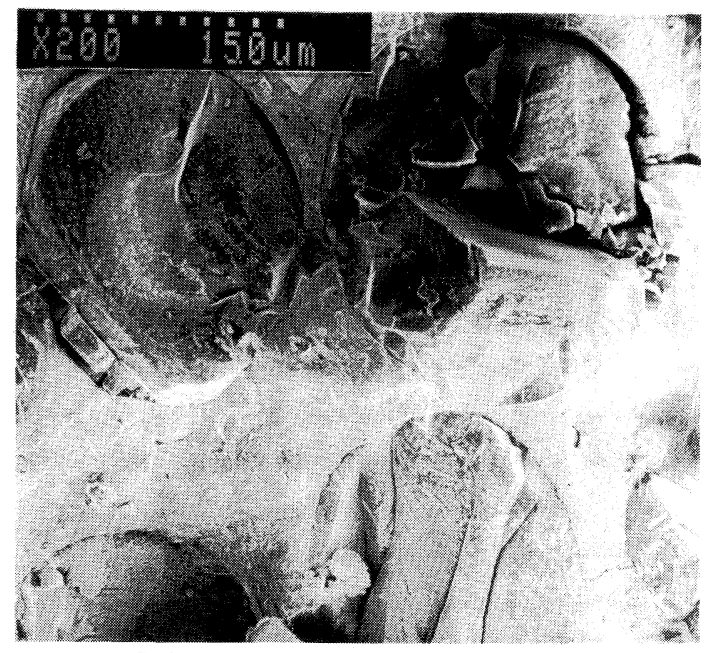

写真-5 写真 4 の中央左の気泡部の拡大

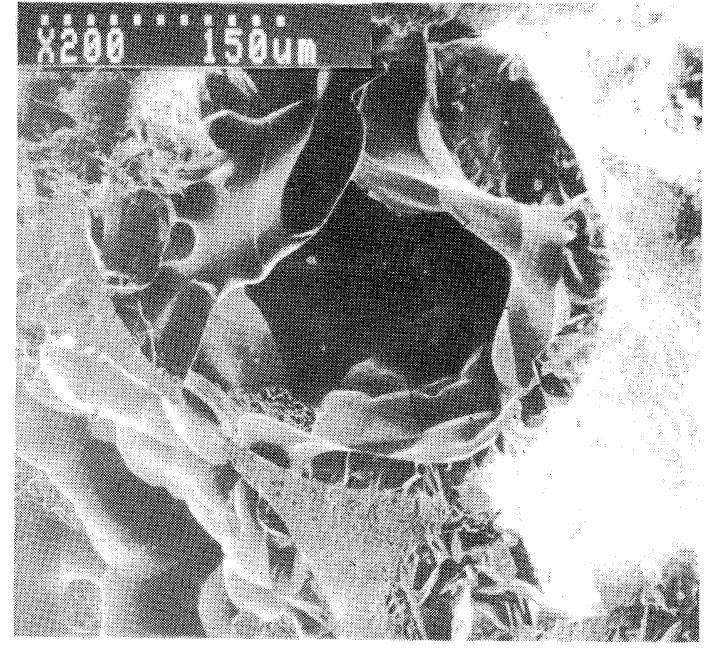

写真-2 写真 1 の右上の小気泡部の拡大

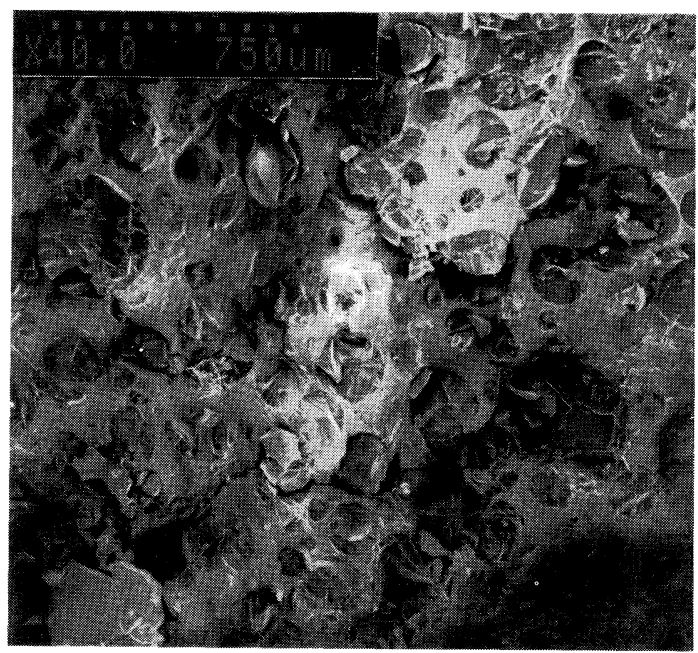

写真-4 飽水度 78\%で凍結した ALC の気泡表面の水

の前兆を長さ変化や動弾性率の変化などから検出するこ とで知られるものであるから，目立った損傷が見られな いのはむしろ当然といえる。しかし限界飽水度に近い飽 水度の試料でも, 写真-2 に示すような直径 $100 \mu \mathrm{m}$ 以下 の小気泡に挄いては, 気泡のかなりの部分が氷で占めら れて㧍り，厚い水の膜による中空の球のような形状とな っている。さらに小さい気泡では飽水度 $78 \%$ の場合と 同様に完全に氷で埋められている。このような気泡にお いては，未凍結水がマトリックス部から移動し，自由に 水結することがこれ以上は困難な状態であり，部分的に 圧力が高まる可能性を否定できない。このことは, 長さ 変化の測定で S $c r$ 付近から膨張が始まることと符合す る。以上の挙動を模式図にまとめて図-7に示す。

Aldrian $^{20)}$ や Gruble $^{21)}$ はセメントペースト中の気泡 


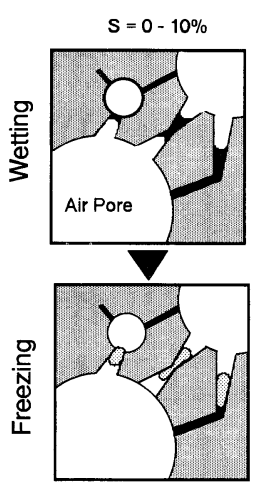

No Change

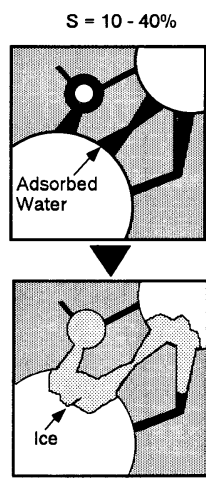

Contraction



Swelling
図-7 ALC の空隙構造と限界飽水度の関係の模式図

に析出した氷を低温の走査電子顕微鏡で観察したが，こ のときの含水率などの測定条件は不明である。Monteiro ら ${ }^{22)}$ は水セメント比 0.4 , 連行空気量 8 12\%のセメン トペーストを 3 日間水中養生した後， $-7{ }^{\circ} \mathrm{C}$ で凍結さ せ，気泡表面に析出した水を観察した。しかし，含水率 を厳密に調整した試料についての観察は今回が初めてと 思われる。

\section{4 限界飽水度と空隙構造の関係}

ALCでは，気泡の量をコントロールすることによっ てかさ密度 $d$ を変えることができるが, 真密度 $d s$ 及び マトリックスのかさ密度 $d m$ はほぼ一定と考えることが できる。そこでかさ密度 $d$ が変化するとき，S $c r$ を $d$ の 関数として求めることを考える。上記の実験の結果から 得られたように，S cr はマトリックス部の空隙に加え て, 気泡部の一部にも水分が存在する状態であるから, マトリックス部分の空隙量 $V p m$ の全空隙量 $V p$ に対す る割合 $V p m / V p$ ，また気泡部分の空隙量 $V p a$ の全空隙 量に対する割合 $V p a / V p$ を用いると,

$$
S c r=V p m / V p+(V p a / V p) \cdot a
$$

と表すことができる。ここで $a$ は 1 より小さな正の数で



次にかさ密度 $d$ を変数として, 真密度 $d s$, マトリッ クス部分のかさ密度 $d m$ を用いて(2)式を書きな抢せば,

$$
\begin{aligned}
& S c r=d \cdot(d s-d m) / d m(d s-d) \\
& +\{d s(d m-d) / d m(d s-d)\} \cdot a
\end{aligned}
$$

となる。この式に $d s=2.62, d m=0.95$ を代入し， さ らに今回の測定値として $S c r=0.44, d=0.503$ を用い ると $a=0.06$ が得られる。即ち, 限界飽水度の状態と はALCのマトリックス部分に存在する細孔が飽水状態 となり，さらに気泡部分の約 $6 \%$ へ水分が浸入した状態 であるということができる。この $a$ の值は直径 $100 \mu \mathrm{m}$ 以下の小気泡の大きさの分布に依存して变わるものと考 えられる。



図-8ＡLCのかさ密度と限界飽水度の関係

含水率を変化させた ALC の凍結時の寸法変化の測定 は, Nerenst-Berger ${ }^{6)}$, Larsson-Purins ${ }^{7}$, Stefanski ${ }^{23)}$,

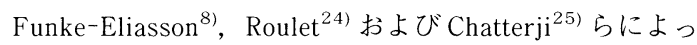
て報告されて抢り，本実験と同様にある飽水度を限界と して収縮から䐍張に転ずることが報告されている。この 文献の中から RILEM の定義にしたがって Scr を求めて いるもののみを引用し，今回の測定值，計算值と共に 図-8に示した。

Scr はかさ密度の増加に従い大きくなる傾向にある が, これは材料の強度が増したからではなく, 細孔量が 増加したためと考えられる。

\section{4.まと め}

RILEM の定める “限界飽水度法”に基づき，ALC の 限界飽水度と空隙構造の関係を明らかにすることを目的 として研究を行った。その主要な結果をまとめると次の とおりである。

（1）吸着水分子層が 0 ２0 となる様含水率を調整した $\mathrm{ALC}$ 試料について, $-70{ }^{\circ} \mathrm{C}$ までの示差走査熱量分析を 行なったところ，2分子層までは実用上不凍結水である こと, 3 分子層から 6 分子層までの吸着水は $-37{ }^{\circ} \mathrm{C}$ 付 近で凍結することを観察した。従って限界飽水度法に規 定される凍結温度領域では 6 分子層までの水分は未凍結 水として存在する。また凝固点降下は固体表面からの拘 束力によって生じて扔り，末凍結水は固体と水との間に 存在するものと考えられる。

（2）飽水度（空隙基準の含水率）を 5 ～70\%に調整し たALC 試料について凍結中の長さ变化の測定を行な い, 限界飽水度を求めたところ, かさ密度 0.355 , 0.503，0.641についてそれぞれ約 38，44，52\%であっ た。この限界飽水度は ALC 空隙中の細孔（マトリック 又部分の空隙）がすべて水分で满たされ，さらに一部の 小気泡にも吸水が進行している含水状態に対応してい 
る。

限界飽水度以下の含水状態の大部分の試料は凍結過程 で熱収縮値よりもさらに収縮した。この含水状態では気 泡内に氷が成長できる余地が十分あるため, 未凍結水が 氷結する際に常圧を維持できることも理由のひとつと考 えられる。

（3）限界飽水度に調整された ALC 試料を $-15{ }^{\circ} \mathrm{C}$ で凍 結させ, 低温走査電顕で直接観察を行ない, 気泡表面に 析出した水を確認した。未凍結水は吸着水膜として固体 と水との間に存在するので, 水晶析出が気泡表面に部分 的に生ずる限り, 吸着水は自由に移動でき圧力は上昇し ない。しかし, 直径が $100 \mu \mathrm{m}$ 以下の比較的小さな気泡 中では氷が圧倒的に多く, 厚い氷の膜による中空球に近 い形態をとることも観察された。このような状態は未凍 結水が移動して自由に氷結する場を失い, 膨張につなが る前兆となっているものと考えられる。

（4）以上の実験結果から，限界飽水度に於ける ALC 空隙中の水分の配置は, すべての細孔と一部の小気泡が 水分で満たされている状態であると考え, 限界飽水度を ALCのかさ密度の関数として数式的に導いた。計算值 は過去に測定されたかさ密度の異なるALCについての 限界飽水度の值と良く一致した。また, 耐凍結融解性の 向上を意図した場合, 細孔レベルの空隙と気泡レベルの 空隙とが明確に分離し, この二つの空隙領域を繫ぐ小気 泡が存在しない様な空隙構造を有することが有効である う。

[謝 辞］実験を行なうにあたり（侏ミサワホーム 総合研究所の岩崎勝氏のご協力を頂いた。また日本大学 笠井芳夫教授には貴重な助言を賜った。記して謝意を表 する次第である。

\section{参 考 文 献}

1) Fagerlund, G. : The Critical Degree of Saturation Method of Assessing the Freeze/Thaw Resistance of Concrete, Mater. Constr. , 10, 58, pp. 217-229, 1978

2）桑島隆一, 藤田嘉夫, 高田宣之: 海水と凍結融解作用を 受けるコンクリートの強度と変形, 土木学会北海道支部 論文報告集, 40, pp. 534-539, 1984

3）千歩 修, 鎌田英治, 洪 悦郎, 田畑雅幸: 多孔質無機 材料の凍結融解を伴わない凍害劣化とその評価法, 日本 建築学会構造系論文報告集, 367, pp. 23-29, 1986

4）三森敏司, 大楽隆男：ALC の耐凍害性に関する一実験, 釧路工業高等専門学校紀要, 20, pp. 99-108, 1986

5) Tada, S. , Nakano,S. : Microstructural Approach to Properties of Moist Cellular Concrete, Autoclaved Aerated Concrete-Moisture and Propties, ed. F. H. Wittmann, Elsevier, pp. $71-88,1983$
6) Nerenst, P. , Berger, O. : Determination of Freezing Resistance of Gas Concrete under Severe Conditions, Proc. RILEM Int. Symp. Durability of Concr. Prague, 3, pp. 15-41, 1969

7) Larsson, L- E. , Purins, E. : Determination of the Critical Degree of Saturation for Autoclaved Lightweight Aerated Concrete by Studying Deformation in Single-Cycle Freezing Tests, Int. J. Lightweight Concr. , 2, 1, pp. 33-41, 1980

8) Funke, K. , Eliasson, B. : Hoegisolerande Laettbetong som baerande element, Byggdok, Stockholm, 369, 1978

9）多田眞作, 岩崎 勝：気泡コンクリートの水分と性質 (5)吸着水の相変化の測定, 日本建築学会大会学術講演梗 概集，pp. 555-556， 1984

10）多田眞作：ALC の空隙構造と水分特性, コンクリート工 学論文集, 1-1, pp. 155-164, 1990

11) Bager, D. H. , Sellevold, E. J. : Ice Formation in Hardened Cement Paste, Part I, II, Cem. Concr. Res. , 16, 56, pp. 709-720, 835-844, 1986

12) Sellevold, E. J. , Bager, D. H. : Low Temperature Calorimetry as a Pore Structure Probe, Proc. 7th Int. Congr. Chem. Cem., Paris, pp. 394-399, 1980

13) Stockhausen, N. , Dorner, H., Zech, B., Setzer, M. J. : Un tersuchung von Gefrievorgangen in Zementstein mit Hilfe der DTA, Cem.Concr. Res. , 9, pp. 783-794, 1979

14) Nakamura, M. , Nabika, Y., Okuda, S : Phase Transitions of Water in Brick During Cooling, Am. Ceram. Soc. Bull. 64, 12, pp. $1567-1570,1985$

15) Nakamura, M. , et. al. : Phase Transitions of Water in Brick During Cooling : II, Effect of Cooling Rate, Presence of Ice Nucleation Substances, and Duration of Time on Phase Transition Behaviors, Am. Ceram. Soc. Bull. , 66, 7 , pp. 1116-1119, 1987

16）中村邦雄：示差走查熱量計（DSC）による吸着水の分 析, 神奈川県工業試験所研究報告, 51, pp. 33-36, 1987

17）若松利男, 佐藤 泰: 差動熱量計によるショ糖, 塩化ナ トリウム及びタンパク溶液中の不凍水量の測定, 日本農 芸化学会誌, 53, 12, pp. 415-420, 1979

18）中村雅彦ほか：表面改質シリカ上の水の相変化：II 低温 DSC による検討，材料 (掲載予定)，1990

19) Conway, B. E. : The State of Water and Hydrated Ions at Interfaces, Adv. Colloid Interface Sci. , 8, pp. 91-212, 1977

20) Aldrian, A. F. : Study on Frozen Specimen in the SEM, Micron, 11, pp. 261-265, 1980

21) Gruble, P. : Uber die Rolle des Eises in Gefuge Zemenge bundener Baustoffe, Beton, 31, 2, pp. 54-58, 1981

22) Monteiro, P. J. M. , Rashed, A. I. , Bastacky, J., Hayes, T. L. : Ice in Cement Paste as Analyzed in the Low-Temperature Scanning Electron Microscope, Cem. Concr. Res. , 19, pp. 306-314, 1989

23) Stefanski, A. : Some Properties of Moistened Gas Concrete in a Frozen State, Build. Sci. , 6, pp. 107-114, 1971

24) Roulet, C. A. : Expansion of Aerated due to Frost-Determ ination of Critical Saturation, Autoclaved Aerated Con crete-Moisture and Properties, ed. F. H. Wittmann, Else vier, pp. 157-169, 1983

25) Chatterji, S. : Freezing of Aqueous Solutions in a Porous Medium. I, Freezing of Air-Entraining Agent Solutions, Cem. Concr. Res., 15, pp. 13-20, 1985

(原稿受理年月日：1990 年 7 月 10 日) 


\title{
Pore Structure and Freezing Behavior of Autoclaved Lightweight Concrete
}

\author{
By Shinsaku Tada
}

Concrete Research and Technology, Vol. 2, No. 1, Jan. 1991

Synopsis Microstructural aspect of the Critical Degree of Saturation for Freeze/Thaw Resistance (Scr) of Autoclaved Lightweight Concrete (ALC) was studied. Measurement of the phase transition of adsorbed water, length chage during freezing and the cryo-SEM observation of the microscopic ice segregation on air pores were carried out. It was proven that $\mathrm{Scr}$ is a moisture content slightly higher than capillary saturation, and an analytical formula of $\mathrm{Scr}$ as a function of bulk density of ALC was derived.

Keywords : ALC, pore structure, freezing behavior, critical degree of saturation, adsorbed water, length change 